ORIGINAL ARTICLE

\title{
Physical and Biological Evidence in Sexual Assault Cases Reported in District Rawalpindi
}

\author{
TASNEEM MURAD ${ }^{1}$, SUNDUS AMBREEN ${ }^{2}$, NOUREEN HAFEEZ ${ }^{3}$, FAISAL KHAN ${ }^{4}$, JAHANZAIB ${ }^{5}$, HASSAN TARIQ ${ }^{6}$ \\ ${ }^{1}$ Assistant Professor Forensic Medicine and Toxicology Department, Islamic International medical collage Riphah International University \\ Islamabad \\ ${ }^{2}$ Professor Forensic Medicine and Toxicology Department, Islamic International medical collage Riphah International University Islamabad \\ ${ }^{3}$ Professor, Forensic Medicine Department, Rawal Institute of Health Sciences Islamabad. \\ ${ }^{4}$ Associate Professor Biochemistry Department, Multan Medical and Dental Collage \\ ${ }^{5}$ Associate Professor Department of Physiology, Jahalwan Medical College Khuzdar \\ ${ }^{6} \mathrm{MO}$, MMDC Multan \\ Corresponding author: Dr Tasneem Murad, Email: tasneem.murad@riphah.edu.pk, Contact: 03005319963
}

\begin{abstract}
Forensic medical examination serve two purposes i.e.to preserve mental and physical health of the victim as well as collection of forensic evidence ${ }^{1,2}$. Collection and documentation of evidence whether in form of injures or biological material is help to validate the objects and the accoster's past. ${ }^{3}$ The outline of wounds also has a criminal worth because they are related to the result of lawful proceedings ${ }^{4}$. The works assessment explores the variables linked to genital harm occurrence and places that are informed in a sequence of surveying examinations of medicinal proceedings ${ }^{5}$.The occurrence of perfect indication of erotic harms in the U.S. ranges from $5-27 \%$, in Italy $11.5 \%$, in Thailand $42 \%$ and in Denmark 38\%. In Israel, as in another place in the countries, few cases of erotic stabbing in children have vibrant indication of a erotic style. $6,7,8,9$.

Objective: To evaluate incidence and comparison of physical and biological evidence in victims of sexual assault and their relation to time interval between examination and incident.

Methodology: The retrospective cross sectional study was placed during June 2019 to December 2020 on cases reported in the DHQ Hospital Rawalpindi with follow up reports. Total 108 cases were reported during this period. Data was collected from DHQ Hospital Rawalpindi with follow up reports. Examination results were included presence and absence of physical injuries located genital region and other parts of the body, and presence and absence of biological evidence. The fallouts of investigation were linked to parameters such as sex, age and length of time since assault. Data was analyzed by using SPSS version 19

Results:

Female victim: Out of 108 cases 77 was female.61\% was unmarried and $39 \%$ was married (Figure 1). $44.2 \%$ cases was fall between age range of 16 -20years. $2.6 \%$ cases between age group of $45-50$ years.51.9\% cases belong to rural area. While $48.1 \%$ cases belong to urban. Vaginal swab was positive in $79.2 \%$.genital injuries was present in $13 \%$ cases. $11.7 \%$ married and $1.3 \%$ unmarried. Other injuries present in $6.5 \%$ married.7.8\%unmarried. Fresh hymen injuries present in $13 \%$.old in $41.6 \%$.

Male victims: Total 31 in number.67.7\%in rural area ,while $32.3 \%$ in urban.45.2\% (14)between age group $11-15$ years .Anal swab was positive in $64.5 \%$.(20 in number).Bleeding was present in $32.3 \%(10)$ cases. Bruises in $41.9 \%$.abrasion was present in $48.4 \% .(15) 25 \%$ in $11-15$ years age group. Genital injuries was present in $45.2 \%(14)$.other injuries $28.1 \%$.anal swab with injuries positive in $34.4 \%$.negative in $12.5 \%$. Finding on clothes was present on $12.5 \%$.

Conclusion \& Recommendations: Rape or sexual assault in the absence of prior sexy knowledge, genital or physique harms are usually found in adolescents. The possibility of rape in nonappearance of any hurt, with or deprived of permission cannot be excluded. A competent forensic examiner must examines and follow up the victims of sexual violence. The forensic examiner must have technical and scientific skills that are medicinal and stabbing history taking, whole body examination, and organic article collects, recording damages, clinical pediatric practice, interpretation of findings and reports and prosecution.
\end{abstract}

Keywords: Genital harms, adolescent, body injuries, Prosecution

\section{INTRODUCTION}

Forensic medical examination serve two purposes i.e.to preserve mental and physical health of the victim as well as collection of forensic evidence 1,2. Collection and documentation of evidence whether in form of injures or biological material is help to validate the objects and the accoster's past. ${ }^{3}$ The outline of wounds also has a criminal worth because they are related to the result of lawful proceedings ${ }^{4}$. The works assessment explores the variables linked to genital harm occurrence and places that are informed in a sequence of surveying examinations of medicinal proceedings ${ }^{5}$.The occurrence of perfect indication of erotic harms in the U.S. ranges from $5-27 \%$, in Italy $11.5 \%$, in Thailand $42 \%$ and in Denmark $38 \%$. In Israel, as in another place in the countries, few cases of erotic stabbing in children have vibrant indication of an erotic style. ${ }^{6,7}$,

Timing of the examination requires consideration of each of these objectives. In cases of acute sexual assault, emergent examinations may be needed to identify injury, collect forensic evidence, and provide infection and pregnancy prophylaxis. ${ }^{8}$

Genital injury was described by injury prevalence, frequency, and anatomical locations of injuries. ${ }^{9}$ 


\section{METHODOLOGY}

The retrospective cross sectional study was placed during June 2019 to December 2020 on cases reported in the DHQ Hospital Rawalpindi with follow up reports. Total 108 cases were reported during this period. Data was collected from DHQ Hospital Rawalpindi with follow up reports. Examination results were included presence and absence of physical injuries located genital region and other parts of the body, and presence and absence of biological evidence .The fallouts of investigation were linked to parameters such as sex, age and length of time since assault. Data was analyzed by using SPSS version 19

\section{RESULTS}

Female victim: Out of 108 cases 77 was female.61\% was unmarried and $39 \%$ was married (Figure 1). $44.2 \%$ cases was fall between age range of $16-20$ years. $2.6 \%$ cases between age group of $45-50$ years. $51.9 \%$ cases belong to rural area.while $48.1 \%$ cases belong to urban.

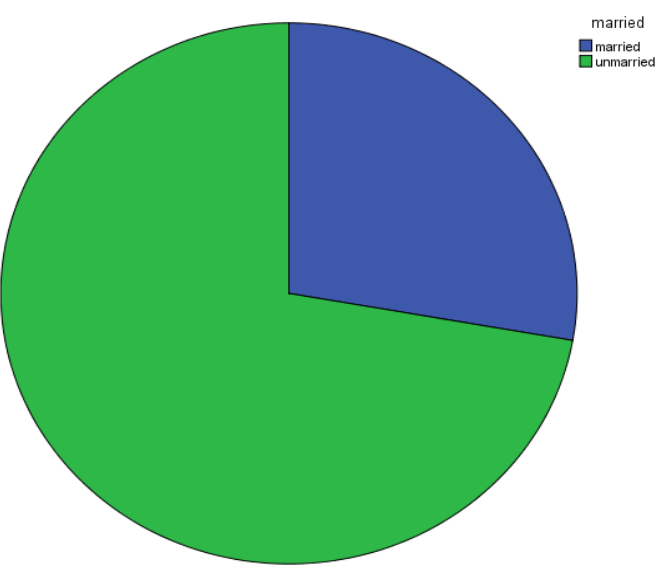

Vaginal swab was positive in $79.2 \%$.genital injuries was present in $13 \%$ cases. $11.7 \%$ married and $1.3 \%$ unmarried. Other injuries present in 6.5\%married.7.8\% unmarried (Table-1).fresh hymen injuries present in $13 \%$.old in $41.6 \%$.

Table No 1

\begin{tabular}{|l|l|l|l|}
\hline Type of injury & Laceration & Bruise & Abrasion \\
\hline Present & 18 & 21 & 25 \\
\hline Absent & 78 & 75 & 71 \\
\hline Total no of cases 108 & & & \\
\hline & & & \\
\hline
\end{tabular}

Male victims: Total 31 in number.67.7\%in rural area , while $32.3 \%$ in urban.45.2\% (14)between age group $11-15$ years .Anal swab was positive in $64.5 \%$.(20 in number).Bleeding was present in $32.3 \%$ (10)cases. Bruises in $41.9 \%$.abrasion was present in $48.4 \% .(15) 25 \%$ in $11-15$ years age group. Genital injuries was present in $45.2 \%(14)$.other injuries $28.1 \%$.anal swab with injuries positive in $34.4 \%$.negative in $12.5 \%$.Finding on clothes was present on $12.5 \%$.

\section{DISCUSSION}

After an allegation of rape or sexual assault, genital and or body injuries are not routinely found in adolescent. The absence of injury does not exclude the possibility of intercourse, whether with or without consent. ${ }^{10,11,12}$ Out of 41 physical abuses was detected in $37(39 \%)$ cases in anogentital area. Recent injuries in 5persons clear evidence in $12 \%$ cases $.80 \%$ injuries identified in first 24 hours.83\% females.(Israel).out of 101 case extra genital injuries present in 49 woman,anogenital injuries in 14 cases.(Norway).out of 203 cases $39 \%$ had ano genital injuries examined during 24 hours have more documented injuries.(USA)77\% will not sustain genital injuries (UK) .Ninty five women out of 165, in the 18-27 year oldness extent may also replicate a culture's accultimize approach towards women based on moral values. ${ }^{13,14}$

\section{CONCLUSION \& RECOMMENDATIONS}

Rape or sexual assault in the absence of prior sexy knowledge, genital or physique harms are usually found in adolescents. The possibility of rape in nonappearance of any hurt, with or deprived of permission cannot be excluded. A competent forensic examiner must examines and follow up the victims of sexual violence. The forensic examiner must have technical and scientific skills that are medicinal and stabbing history taking, whole body examination, and organic article collects, recording damages, clinical pediatric practice, interpretation of findings and reports and prosecution.

\section{REFERENCES}

1. O I-H, AV C. Forensic medical examination of adolescent and adult victims of sexual violence. Best Pract Res Clin Obstet Gynaecol [Internet]. 2013 [cited 2021 Jul 27];27(1):91-102. Available from: https://pubmed.ncbi.nlm.nih.gov/23036587/

2. Möller AS, Bäckström T, Söndergaard HP, Helström L. Patterns of Injury and Reported Violence Depending on Relationship to Assailant in Female Swedish Sexual Assault Victims: $\quad$ http://dx.doi.org/101177/0886260512441261 [Internet]. 2012 May 14 [cited 2021 Jul 27];27(16):3131-48. Available from: https://journals.sagepub.com/doi/abs/10.1177/08862605124 41261

3. Mizrachi $\mathrm{Y}$, Bar J, Barda G. Characteristics and trends of sexual assaults in Israel - A large cohort study of 3941 victims. Acta Obstet Gynecol Scand. 2020 Jul 1;99(7):9417.

4. SOMMERS MS. DEFINING PATTERNS OF GENITAL INJURY FROM SEXUAL ASSAULT: A Review. Trauma Violence Abuse [Internet]. 2007 Jul [cited 2021 Jul 27];8(3):270. Available from:/pmc/articles/PMC3142744/

5. Kelly DL, Larkin HJ, Cosby CD, Paolinetti LA. Derivation of the Genital Injury Severity Scale (GISS): a concise instrument for description and measurement of external female genital injury after sexual intercourse. J Forensic Leg Med. 2013 Aug;20(6):724-31.

6. Friis-Rødel AM, Leth PM, Astrup BS. Stranger rape; distinctions between the typical rape type and other types of rape. A study based on data from Center for Victims of Sexual Assault. J Forensic Leg Med. 2021 May 1;80.

7. [The prevalence of physical evidence in the anogenital area in sexual assault cases of children in Israel] - PubMed [Internet]. [cited 2021 Jul 27]. Available from: https://pubmed.ncbi.nlm.nih.gov/22352280/

8. HAGEMANN CT, STENE LE, MYHRE AK, ORMSTAD K, SCHEI B. Impact of medico-legal findings on charge filing in cases of rape in adult women. Acta Obstet Gynecol Scand [Internet]. 2011 Nov 1 [cited 2021 Jul 27];90(11):1218-24. 
Available

from: https://obgyn.onlinelibrary.wiley.com/doi/full/10.1111/j.16000412.2011.01246.x

9. Baker RB, Sommers MS. Relationship of Genital Injuries and Age in Adolescent and Young Adult Rape Survivors. J Obstet Gynecol Neonatal Nurs [Internet]. 2008 May 1 [cited 2021 Jul 27];37(3):282-9. Available from: https://onlinelibrary.wiley.com/doi/full/10.1111/j.15526909.2008.00239.x

10. Jina R, Jewkes R, Vetten L, Christofides N, Sigsworth R, Loots L. Genito-anal injury patterns and associated factors in rape survivors in an urban province of South Africa: A crosssectional study. BMC Womens Health. 2015 Mar 27;15(1).

11. C W, I M. Adolescent complainants of sexual assault; injury patterns in virgin and non-virgin groups. $\mathrm{J}$ Clin Forensic Med [Internet]. 2006 May [cited 2021 Jul 27];13(4):172-80.
Available from: https://pubmed.ncbi.nlm.nih.gov/16564196/

12. Anderson S, McClain N, Riviello RJ. Genital Findings of Women After Consensual and Nonconsensual Intercourse. J Forensic Nurs. 2008 Jun 28;2(2):59-65.

13. Laitinen FA, Grundmann O, Ernst EJ. Factors that influence the variability in findings of anogenital injury in adolescent/adult sexual assault victims: A review of the forensic literature. Am J Forensic Med Pathol. 2013 Sep;34(3):286-94.

14. Christian CW. Timing of the Medical Examination https://doi.org/101080/105387122011607424 [Internet]. 2011 Sep [cited 2021 Jul 27];20(5):505-20. Available from: https://www.tandfonline.com/doi/abs/10.1080/10538712.201 1.607424 